\title{
Penerapan Metode Pembelajaran Bermain Peran pada Materi Sistem Pencernaan untuk Meningkatkan Aktivitas dan Hasil Belajar Peserta Didik
}

\author{
Arif Sulistiyohadi \\ Madrasah Tsanawiyah Negeri 7 Ngawi \\ Jl. Ketanggung-Sine, Ketanggung, Kec. Sine, Kabupaten Ngawi, Jawa Timur 63253 \\ *Email: arifsulistyohadi@gmail.com
}

\begin{abstract}
Abstrak
Tujuan penelitian ini yaitu mendeskripsikan pengaruh penerapan metode pembelajaran bermain peran terhadap aktivitas dan hasil belajar peserta didik MTsN 7 Ngawi. Penelitian ini merupakan penelitian tidakan kelas dengan parameter yang diamati yaitu persentase aktivitas belajar peserta didik dan tingkat ketuntasan yang mengindikasikan hasil belajar peserta didik. Penelitian dilaksanakan di MTsN 7 Ngawi pada peserta didik kelas VIII B sebagai subyek penelitian. Penelitian dilaksanakan dalam tiga siklus pembelajaran. Hasil belajar peserta didik diukur melalui pemberian tes formatif, sedangkan aktivitas belajar peserta didik dinilai menggunakan lembar obserbasi aktivitas siswa. Nilai hasil belajar dianalisi menggunakan rumus persentase ketuntasan peserta didik, sedangkan aktvitas peserta didik dianalisis secara deskriptif. Hasil penelitian ini menunjukkan bahwa persentase peserta didik aktif dalam pembelajaran mengalami peningkatan dari siklus I sampai siklus III secara berturut-turut yaitu $60.86 \%, 73,91 \%$, dan $91,30 \%$. Hasil belajar peserta didik juga mengalami peningkatan ditunjukkan dengan rata-rata nilai tes formatif yaitu $64,78,78,26$, dan 86,95 . Penelitian ini disimpulkan bahwa penerapan metode pembelajaran siswa pada materi sistem pencernaan dapat meningkatkan aktivitas dan hasil belajar peserta didik.
\end{abstract}

Kata kunci: aktivitas belajar, bermain peran, hasil belajar, metode pembelajaran

\begin{abstract}
The purpose of this study is to describe the effect of the application of role-playing learning methods on the activities and learning outcomes of students at MTSN 7 Ngawi. This research is a classroom action research with the observed parameters, namely the percentage of student learning activities and the level of completeness that indicates student learning outcomes. The research was carried out at MTSN 7 Ngawi in class VIII B students as research subjects. The research was carried out in three learning cycles. Student learning outcomes are measured through the provision of formative tests, while student learning activities are assessed using student activity observation sheets. The value of learning outcomes was analyzed using the formula for the percentage of students' completeness, while the students' activities were analyzed descriptively. The results of this study indicate that the percentage of active students in learning has increased from cycle I to cycle III, respectively, namely $60.86 \%, 73.91 \%$, and $91.30 \%$. Student learning outcomes also increased as indicated by the average formative test scores, namely 64.78, 78.26, and 86.95. This study concluded that the application of student learning methods on the material of the digestive system can increase the activity and learning outcomes of students.
\end{abstract}

Keywords: learning method, role playing, student activities, student result test

\section{PENDAHULUAN}

Pandemi COVID-19 mengakibatkan berbagai perubahan aktivitas masyarakat, pendidikan dan ekonomi negara. Adanya pandemi COVID-19 menyebabkan perubahan pembelajaran dari sistem luring (luar jaringan) menjadi pembelajaran daring (dalam jaringan). Pembelajaran daring ini memiliki kelebihan dan kelemahan. Pembelajaran daring dirasa efektif karena dapat dilakukan di mana saja, namun demikian pembelajaran daring menunjukkan beberapa kendala seperti siswa kesulitan mengikuti pembelajaran karena kendala tidak punya smartphone, kendala signal, tidak punya kuota atau kuota habis dan 


\section{JPSP: Jurnal Penelitian Sains dan Pendidikan}

https://e-journal.iain-palangkaraya.ac.id/index.php/mipa/

banyak penugasan kepada siswa di rumah. Hal inilah yang menyebabkan siswa kurang bersemangat untuk mengikuti kegiatan belajar mengajar dan berakibat penguasaan materi berkurang dan prestasi menurun.

Penurunan kasus COVID-19 saat ini memberikan kebijakan pembelajaran kombinasi daring dan luring, dengan persentase pembelajaran luring yaitu 25\%. Hal ini menjadi tantangan bagi guru untuk mengembangkan sistem belajar yang kreatif, inovatif, efektif dan efisien serta meningkatkan semangat belajar siswa. Dewasa ini masih banyak kita temukan permasalahan pembelajaran pada pendidikan dasar dan menengah, yaitu masih adanya pola pembelajaran yang sangat teoritis, kurang inovasi, dan bervariasi. Kegiatan pembelajaran yang berlangsung di kelas masih berorientasi pada buku, kurang dikaitkan dengan situasi kondisi, dan lingkungan di mana siswa berada serta keadaan siswa pada saat itu. Selain itu kegiatan belajar dengan metode ceramah yang diikuti dengan penugasan membuat siswa merasa bosan belajar dan kurang termotivasi (Cimer, 2012).

Berdasarkan hasil observasi awal yang dilakukan oleh peneliti di MTsN 7 Ngawi, diketahui terdapat penurunan aktivitas siswa pada proses pembelajaran. Terdapat tiga faktor yang mengakibatkan penurunan aktivitas belajar siswa yaitu faktor dari siswa, faktor dari guru, dan faktor madrasah. Siswa cenderung bosan, malas, dan letih saat melaksanakan proses pembelajaran yang monoton. Guru kurang memiliki strategi dan metode pembelajaran yang dapat meningkatkan aktivitas siswa. Selain itu, faktor madrasah yang memiliki jam pelajaran yang padat dan kurangnya sarana juga menyebabkan semakin rendahnya aktivitas siswa. Rendahnya aktivitas siswa juga berdampak pada rendahnya nilai hasil belajar siswa. Oleh karena itu diperlukan sebuah strategi atau metode pembelajaran yang dapat meningkatkan hasil belajar dan aktivitas siswa.

Penerapan metode pembelajaran yang inovatif menjadi salah satu alternatif untuk meningkatkan pemahaman dan peningkatan aktivitas belajar siswa (Roestiyah, 2012). Salah satu metode pembelajaran yang dapat diterapkan di sekolah dasar dan tingkat menengah yaitu metode bermain peran atau role playing. Metode role playing merupakan suatu cara penguasaan bahan-bahan pelajaran melalui pengembangan imajinasi dan penghayatan siswa. Pengembangan imajinasi dan penghayatan itu dilakukan siswa dengan memerankannya sebagai tokoh hidup atau benda mati (Ismail, 2009).

Penerapan metode belajar dengan role playing ini banyak melibatkan siswa dan membuat siswa senang belajar, karena siswa dapat berpartisipasi dan mempunyai kesempatan untuk menunjukkan kemampuannya dalam bekerjasama hingga berhasil, juga merupakan pengalaman belajar yang menyenangkan bagi anak, dengan menerapkan metode bermain peran akan terjadi suasana yang menggembirakan bagi siswa selama mereka belajar (Sinaga dkk., 2016; Yunus dkk., 2019). Metode role playing dapat meningkatkan pemahaman siswa terhadap materi pelajaran yang sedang dipelajari, karena dengan melakukan peran suatu kasus pada 


\section{JPSP: Jurnal Penelitian Sains dan Pendidikan}

https://e-journal.iain-palangkaraya.ac.id/index.php/mipa/

materi pelajaran yang sedang dibahas, diharapkan para siswa dapat menghayati lebih kuat terhadap kejadian atau pokok bahasan itu, sehingga pemahaman dan sikap mereka akan semakin meningkat, yang pada akhirnya dapat meningkatkan prestasi belajar dari siswa tersebut (Alfianto, 2015). Berdasarkan uraian tersebut, tujuan dari penelitian ini adalah untuk mendeskripsikan pengaruh penerapan metode pembelajaran bermain peran terhadap aktivitas dan hasil belajar peserta didik MTsN 7 Ngawi.

\section{METODE PENELITIAN}

Penelitian ini menggunakan teknik Penelitian Tindakan Kelas (PTK). Penelitian tindakan kelas dilakukan untuk memecahkan masalah pembelajaran di kelas (Suharsimi, dkk., 2015). Penelitian ini juga termasuk penelitian deskriptif, sebab menggambarkan bagaimana suatu teknik pembelajaran diterapkan dan bagaimana hasil yang diinginkan dapat dicapai.

Penelitian ini bertempat di kelas VIII B MTsN 7 Ngawi tahun pelajaran 2021/2022 pada tanggal 23 Agustus 2021 - 14 September 2021 pada semester gasal Tahun pelajaran 2021/2022. Subyek penelitian adalah siswasiswi kelas VIII B MTsN 7 Ngawi tahun pelajaran 2021/2022 yang berjumlah 23 siswa, terdiri dari 18 perempuan dan 5 laki-laki, pada pokok bahasan Sistem Pencernaan Makanan pada Manusia.

Rancangan penelitian PTK yang digunakan yaitu penelitian tindakan kelas model Kemmis dan Taggart (Arikunto, Suharsimi, 2002), yaitu berbentuk spiral dari siklus yang satu ke siklus yang berikutnya.
Setiap siklus meliputi planning (rencana), action (tindakan), observation (pengamatan), dan reflection (refleksi). Langkah pada siklus berikutnya adalah perencanaan yang sudah direvisi, tindakan, pengamatan, dan refleksi. Sebelum masuk pada siklus I dilakukan tindakan pendahuluan yang berupa identifikasi permasalahan.

Siklus spiral dari tahap-tahap penelitian tindakan kelas yaitu pertama, Rancangan/rencana awal, sebelum mengadakan penelitian peneliti menyusun rumusan masalah, tujuan dan membuat rencana tindakan, termasuk di dalamnya instrumen penelitian dan perangkat pembelajaran. Kedua, Kegiatan dan pengamatan, meliputi tindakan yang dilakukan oleh peneliti sebagai upaya membangun pemahaman konsep siswa serta mengamati hasil atau dampak dari diterapkannya proses pengajaran dengan menggunakan metode bermain peran (role play). Ketiga, Refleksi, peneliti mengkaji, melihat dan mempertimbangkan hasil atau dampak dari tindakan yang dilakukan berdasarkan lembar pengamatan yang diisi oleh pengamat. Keempat, Rancangan/rencana yang direvisi, berdasarkan hasil refleksi dari pengamat membuat rancangan yang direvisi untuk dilaksanakan pada siklus berikutnya. Observasi dibagi dalam tiga siklus, yaitu siklus 1, 2, dan seterusnya, dimana masing siklus dikenai perlakuan yang sama (alur kegiatan yang sama) dan membahas satu sub pokok bahasan yang diakhiri dengan tes formatif di akhir masing putaran. Siklus ini berkelanjutan dan akan dihentikan jika sesuai dengan kebutuhan dan dirasa sudah cukup. 


\section{JPSP: Jurnal Penelitian Sains dan Pendidikan}

https://e-journal.iain-palangkaraya.ac.id/index.php/mipa/

Pengumpulan data dilakukan dengan tes formatif dan observasi. Tes Formatif dibuat setelah dilakukan pembelajaran satu sub pokok bahasan dengan tujuan untuk menentukan tingkat pengausaan materi yang telah diberikan, ketercapaian tujuan dan nilai siswa (Arikunto dan Suharsimi, 2002). Observasi digunakan untuk mengetahui dan merekam aktivitas guru dan siswa dalam proses belajar mengajar.

Data dianalisis secara kuantitatif dan kualitatif. Analisa kuantitatif dilakukan dengan merekapitulasi dan menghitung jumlah skor tes formatif. Rata-rata nilai tes formatif dihitung dengan rumus sebagai berikut:

$$
\chi=\frac{\Sigma x}{\Sigma N}
$$

$\mathrm{X}=$ Nilai rata-rata

$\Sigma \mathrm{X}=$ Jumlah semua nilai peserta didik

$\Sigma \mathrm{N}=$ Jumlah peserta didik

Dalam penelitian ini ketuntasan belajar juga diukur untuk menentukan tingkat ketutansan belajar siswa. Menurut Depdikbud (1994), peserta didik telah tuntas belajar apabila telah mencapai skor $65 \%$ atau nilai 65 , dan kelas disebut tuntas belajar bila di kelas tersebut terdapat $85 \%$ yang telah mencapai daya serap lebih dari atau sama dengan $65 \%$. Persentase ketuntasan belajar siswa dihitung dengan rumus sebagai berikut:

$$
P=\frac{\Sigma \text { Siswa yang tuntas belajar }}{\Sigma \text { Siswa }} \times 100 \%
$$

\section{HASIL PENELITIAN}

Pada penelitian ini pengukuran aktivitas belajar siswa dibagi menjadi tiga siklus. Siklus pertama peneliti mempersiapkan perangkat pembelajaran yang terdiri dari rencana pelaksanaan pembelajaran 1 , soal tes formatif 1 dan alat-alat pembelajaran yang mendukung. Adapun proses belajar mengajar mengacu pada rencana pelaksanaan pembelajaran yang telah dipersiapkan. Pengamatan (observasi) dilaksanakan bersamaan dengan pelaksaaan belajar mengajar. Pada akhir proses belajar mengajar untuk siklus I peserta didik diberi tes formatif I dengan tujuan untuk mengetahui tingkat keberhasilan peserta didik dalam menguasai dan memahami materi pembelajaran dalam proses belajar mengajar yang telah dilakukan.

Pada siklus I dengan penerapan cara belajar aktif metode bermain peran (role playing) nilai rata-rata prestasi belajar siswa adalah 64,78 dan ketuntasan belajar mencapai $65,21 \%$ atau ada 15 siswa dari 23 siswa sudah tuntas belajar. Hasil tersebut menunjukkan bahwa pada siklus pertama secara klasikal siswa belum tuntas belajar, karena siswa yang memperoleh nilai $\geq 65$ hanya sebesar $65,21 \%$ lebih kecil dari persentase ketuntasan yang dikehendaki yaitu sebesar $85 \%$. Hal ini disebabkan karena siswa masih belum begitu tahu cara belajar bermain peran, belum aktif dan nyetel dengan pembelajaran menggunakan metode bermain peran (Tabel 1).

Berikutnya, proses belajar mengajar pada siklus II dengan metode bermain peran (role playing) mengacu pada rencana pelaksanaan pembelajaran dengan memperhatikan revisi pada siklus I, sehingga kesalahan atau kekurangan pada siklus I tidak terulang lagi pada siklus II. Pengamatan (observasi) dilaksanakan bersamaan dengan 


\section{JPSP: Jurnal Penelitian Sains dan Pendidikan}

https://e-journal.iain-palangkaraya.ac.id/index.php/mipa/

pelaksanaan kegiatan belajar mengajar. Pada

siklus kedua aktivitas belajar siswa meningkat dari siklus pertama yaitu 71,52 dan ketuntasan belajar mencapai $78,26 \%$ atau ada 18 siswa dari 23 siswa sudah tuntas belajar. Hasil ini menunjukkan bahwa pada siklus II ini ketuntasan belajar secara klasikal telah mengalami peningkatan sedikit lebih baik dari siklus I. Adanya peningkatan hasil belajar siswa ini karena siswa sudah mulai mempelajari lagi materi yang telah diterimanya selama ini dan mulai aktif dan nyetel dengan metode bermain peran (role play).

Pada siklus III, proses belajar mengajar mengacu pada rencana pelajaran dengan memperhatikan revisi pada siklus II, sehingga kesalahan atau kekurangan pada siklus II tidak terulang lagi pada siklus III. Pengamatan (observasi) dilaksanakan bersamaan dengan pelaksanaan belajar mengajar. Pada akhir proses belajar mengajar peserta didik diberi tes formatif III dengan tujuan untuk mengetahui tingkat keberhasilan peserta didik dalam memahami dan menguasai materi pembelajaran pada proses belajar mengajar yang telah dilakukan. Instrumen yang digunakan adalah tes formatif III.

Berdasarkan Tabel 1 diperoleh nilai ratarata tes formatif sebesar 75 dari 23 siswa, yang telah tuntas sebanyak 20 siswa dan 3 siswa belum mencapai ketuntasan belajar. Maka secara klasikal ketuntasan belajar yang telah tercapai sebesar 86,95\% (termasuk kategori tuntas). Hasil pada siklus III ini mengalami peningkatan lebih baik dari siklus II. Adanya peningkatan hasil belajar pada siklus III ini dipengaruhi oleh adanya peningkatan kemampuan siswa dalam mempelajari kembali materi pelajaran yang telah diterapkan selama ini.

Tabel 1. Persentase Keaktifan Siswa Kelas VIII B Pada Tiap Siklus

\begin{tabular}{|c|c|c|c|c|c|c|}
\hline \multirow[b]{2}{*}{ Kelompok } & \multicolumn{2}{|c|}{ Siklus I } & \multicolumn{2}{|c|}{ Siklus II } & \multicolumn{2}{|c|}{ Siklus III } \\
\hline & $\begin{array}{l}\text { Siswa } \\
\text { Aktif }\end{array}$ & $\begin{array}{c}\text { Siswa } \\
\text { tidak aktif }\end{array}$ & $\begin{array}{l}\text { Siswa } \\
\text { Aktif }\end{array}$ & $\begin{array}{c}\text { Siswa tidak } \\
\text { aktif }\end{array}$ & $\begin{array}{l}\text { Siswa } \\
\text { Aktif }\end{array}$ & $\begin{array}{c}\text { Siswa tidak } \\
\text { aktif }\end{array}$ \\
\hline $\begin{array}{l}\text { Kelompok } 1 \\
\text { (6 siswa) }\end{array}$ & 3 & 3 & 4 & 2 & 5 & 1 \\
\hline $\begin{array}{l}\text { Kelompok } 2 \\
\text { (6 siswa) }\end{array}$ & 4 & 2 & 5 & 1 & 5 & 1 \\
\hline $\begin{array}{l}\text { Kelompok } 3 \\
\text { (5 siswa) }\end{array}$ & 3 & 2 & 4 & 1 & 5 & 0 \\
\hline $\begin{array}{l}\text { Kelompok } 4 \\
\text { (6 siswa) }\end{array}$ & 4 & 2 & 4 & 2 & 6 & 0 \\
\hline $\begin{array}{l}\text { Jumlah } \\
\text { \% Aktif }\end{array}$ & $\begin{array}{c}14 \\
60.86 \%\end{array}$ & $\begin{array}{c}9 \\
39.13 \%\end{array}$ & $\begin{array}{c}17 \\
73.91 \%\end{array}$ & $\begin{array}{c}6 \\
26.08 \%\end{array}$ & $\begin{array}{c}21 \\
91.30 \%\end{array}$ & $\begin{array}{c}2 \\
8.69 \%\end{array}$ \\
\hline
\end{tabular}

Tingkat ketuntasan peserta didik kelas menunjukkan peningkatan dari siklus 1 hingga siklus III, sebaliknya persentase siswa yang tidak tuntas menurun. Peningkatan ketuntasan dari siklus I ke siklus II yaitu 13,39\%, sedangkan peningkatan siklus II ke siklus III yaitu 8,69\% (Gambar 1). Secara keseluruhan metode pembelajaran dengan teknik role playing ini dapat meningkatkan keaktifan siswa sebesar 30,44\% dan ketuntasan siswa $21,74 \%$. 


\section{JPSP: Jurnal Penelitian Sains dan Pendidikan}

https://e-journal.iain-palangkaraya.ac.id/index.php/mipa/

Peningkatan yang cukup signifikan ini dapat pembelajaran dengan role playing.

menjadi acuan untuk rekomendasi metode

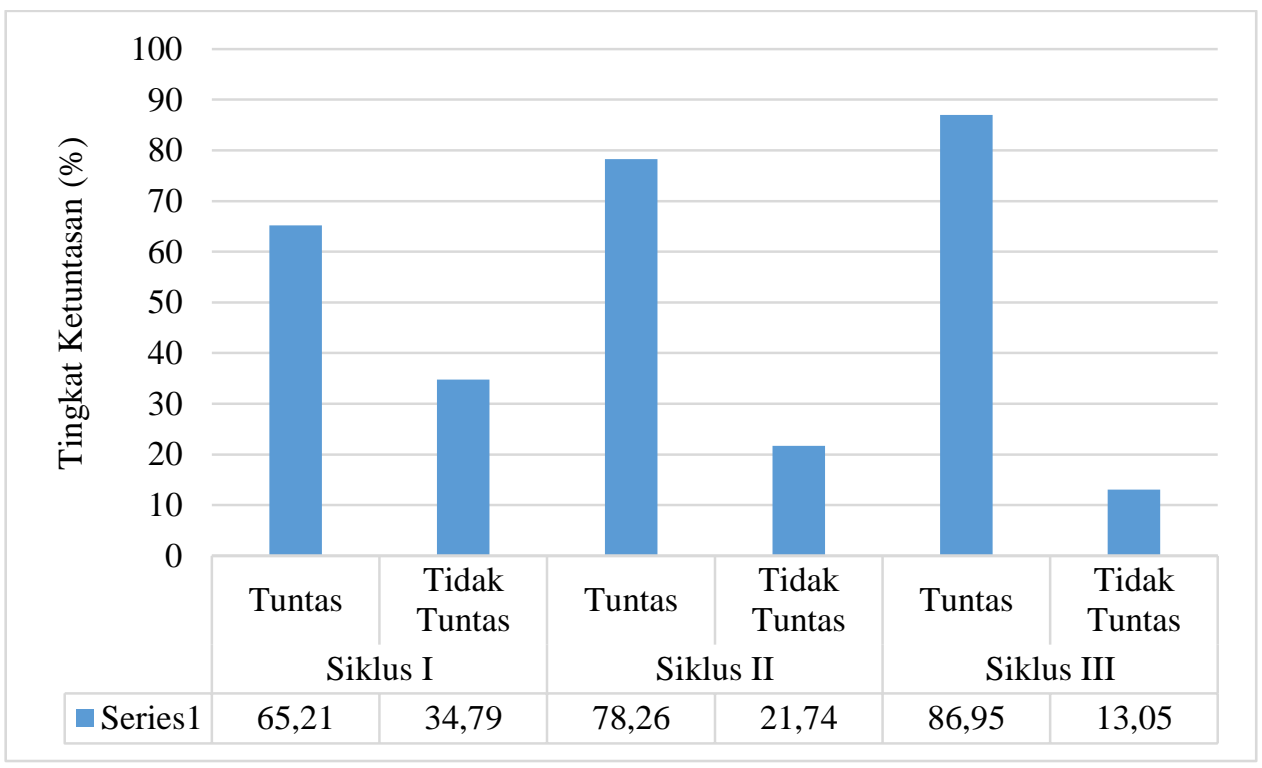

Gambar 1. Tingkat ketuntasan peserta didik Kelas VIII B Pada Tiap Siklus

\section{PEMBAHASAN}

Pada tahap refleksi akan dikaji apa yang telah terlaksana dengan baik maupun yang masih kurang baik dalam proses belajar mengajar dengan penerapan belajar aktif dengan melalui metode bermain peran (role playing). Dari data-data yang telah diperoleh pada penelitian tindakan kelas ini dapat diuraikan sebagai berikut:

1. Selama proses belajar mengajar, guru telah melaksanakan semua pembelajaran dengan baik. Meskipun ada beberapa aspek yang belum sempurna, tetapi persentase pelaksanaannya untuk masing-masing aspek cukup besar.

2. Berdasarkan data hasil pengamatan diketahui bahwa siswa aktif selama proses belajar berlangsung.

3. Kekurangan pada siklus-siklus sebelumnya sudah mengalami perbaikan dan peningkatan sehingga menjadi lebih baik.

4. Hasil belajar siswsa pada siklus III mencapai ketuntasan.

Pada siklus III guru telah menerapkan belajar aktif melalui metode bermain peran (role playing) dengan baik dan dilihat dari aktivitas peserta didik serta hasil belajar peserta didik pelaksanaan proses belajar mengajar sudah berjalan dengan baik. Maka tidak diperlukan revisi terlalu banyak, tetapi yang perlu diperhatikan untuk tindaka $\mathrm{n}$ selanjutnya adalah memaksimalkan dan mempertahankan apa yang telah ada dengan tujuan agar pada pelaksanaan proses belajar mengajar selanjutnya penerapan belajar aktif melalui metode bermain peran (role playing) dapat meningkatkan proses belajar mengajar sehingga tujuan pembelajaran dapat tercapai secara optimal. 


\section{JPSP: Jurnal Penelitian Sains dan Pendidikan}

https://e-journal.iain-palangkaraya.ac.id/index.php/mipa/

Melalui hasil penelitian ini menunjukkan bahwa cara belajar aktif melalui metode bermain peran memiliki dampak positif dalam meningkatkan daya ingat peserta didik. Hal ini dapat dilihat dari semakin mantapnya pemahaman dan penguasaan peserta didik terhadap materi yang telah disampaikan guru dan siswa sendiri secara berkelompok selama ini (ketuntasan belajar meningkat dari siklus I, II, dan III) yaitu masing-masing 65,21\%, 78,26\%, dan 86,95\%. Pada siklus III ketuntasan belajar siswa secara klasikal telah tercapai.

Berdasarkan analisis data, diperoleh aktivitas peserta didik dalam proses cara belajar aktif dengan model bermain peran (role playing) dalam setiap siklus mengalami peningkatan. Hal ini berdampak positif terhadap proses mengingat kembali materi pelajaran yang telah diterima selama ini, yaitu dapat ditunjukkan dengan meningkatnya nilai rata-rata peserta didik pada setiap siklus yang terus mengalami peningkatan.

Hasil penelitian ini sesuai dengan penelitian yang dilaksanakn oleh Mutia dkk. (2021) yang menyatakan bahwa metode bermain peran dapat meningkatkan hasil belajar siswa pada mata pelajaran biologi. Penelitian ini juga sesuai dengan hasil penelitian Alfianto (2015) yang menyebutkan bahwa model pembelajaran bermain peran dapat meningkatkan aktivitas belajar siswa pada kelas VIII SMP.

\section{SIMPULAN}

Penelitian ini dapat disimpulkan bahwa penerapan metode bermain peran (role playing) dapat meningkatkan aktifitas dan hasil belajar siswa dalam pembelajaran IPA di kelas VIII B MTsN 7 Ngawi tahun pelajaran 2021/2022 secara berurutan 30,44\% dan $21,74 \%$..

\section{DAFTAR PUSTAKA}

Suharsimi A, Suhardjono, Supardi. 2015. Penelitian Tindakan Kelas (Edisi Revisi). Jakarta: Rineka Cipta.

Ismail SM. 2009. Strategi Pembelajaran Agama Islam Berbasis PAIKEM. Semarang: Rasail Media Group.

Yunus SR, Sudarto, Andrianto R. 2019.

Pengaruh Metode Pembelajaran Bermain Peran Terhadap Hasil Belajar Peserta

Didik Kelas VII SMP Negeri 24 Bulukumba (Studi Pada Materi Pokok Pencemaran Lingkungan). Jurnal IPA Terpadu. 3(1): 12-19.

Sinaga FN, Huzaifah S, Santoso LM. 2016. Penerapan Model Bermain Peran Pada Pembelajaran Biologi Materi Kode Genetik Dan Sintesis Protein Di SMA Negeri 1 Indralaya Utara. Jurnal Pembelajaran Biologi. 3(2): 214-222.

Cimer A. 2012. What Makes Biology Learning Difficult and Effective: Students Views. Turkey Educational Research and Review, 7 (3): 61-71.

Roestiyah NK. 2012. Strategi Belajar Mengajar. Jakarta: Rineka Cipta.

Alfianto AB. 2015. Penerapan Model Bermain Peran Pada Materi Sistem Pernapasan Terrhadap Aktivitas Dan Hasil Belajar Siswa Kelas VIII SMP N 1 Semen Kediri. 


\section{JPSP: Jurnal Penelitian Sains dan Pendidikan}

https://e-journal.iain-palangkaraya.ac.id/index.php/mipa/

Skripsi. Universitas Nusantara PGRI

Kediri.

Mutia M, Sartiati S, Badariah B. 2021.

Pengaruh Penggunaan Metode Bermain

Peran dengan Media Flashcard terhadap

Hasil Belajar Biologi Siswa Kelas X

Madrasah Aliyah Negeri Laboratorium

Kota Jambi. Skripsi. UIN Sultan Thafa

Saifuddin. 